\title{
Identification of Local Sesars of Tejakula Buleleng Bali with Anomaly Gravity Data Using Second Vertical Derivative Method
}

\author{
Komang Ngurah Suarbawa \\ Physics Study Program, Faculty of Mathematics and Natural Sciences, Udayana University, Badung, Bali, Indonesia \\ Corresponding author email: suarbawa@unud.ac.id \\ I Gusti Agung Putra Adnyana \\ Physics Study Program, Faculty of Mathematics and Natural Sciences, Udayana University, Badung, Bali, Indonesia \\ Email:igaadnyana@unud.ac.id

\section{Elvin Riyono} \\ Physics Study Program, Faculty of Mathematics and Natural Sciences, Udayana University, Badung, Bali, Indonesia \\ Email: elvinriyo@gmail.com
}

\begin{abstract}
Research has been carried out related to subsurface structures in the Tejakula Buleleng Bali area and its surroundings using the gravity method. This study aims to identify the local Tejakula fault. The data used in this study is gravity anomaly data obtained from observations of Geodetic Satellite (GEOSAT). The method used in interpreting the type of disturbance uses the Second Vertical Derivative method, which then produces twodimensional (2D) and three-dimensional (3D) fault model interpretations. Based on the results obtained in the study, the condition of the bouguer gravity anomaly value in the Tejakula area and its surroundings at the research location is in the range of $65 \mathrm{mGal}$ to $185 \mathrm{mGal}$. Meanwhile, based on the Second Vertical Derivative method in determining the type of fault, the Tejakula Fault can be categorized as a mandatory fault with an upward trend. Keywords---fault model, gravity anomaly, SVD, Tejakula fault.
\end{abstract}

\section{Introduction}

The island of Bali is part of a small Sundanese archipelago formed as a result of the subduction of the IndoAustralian plate under the Eurasian plate. The process of subduction is an area where an oceanic plate is pushed under another continental plate or oceanic plate (Buttkus, 2000; Elkins, 1951; McCaffrey \& Nabelek, 1987).

Apart from the existence of a subduction zone, the source of earthquakes can come from active faults found in the sea and on land. One of the earthquake-prone zones on the island of Bali is the Tejakula area, Buleleng. Recorded by the Meteorology, Climatology, and Geophysics Agency, in 2017 itself there was significant seismic activity, where there were 51 earthquake events from May to October 2017. This earthquake event was recorded starting from 9 May to 22 June 2017 with 41 earthquake events and again felt from 21 August to 17 October 2017 with 10 earthquake events. The magnitude range ranges from 1.9 to 3.8 and a depth of 1 to $13 \mathrm{~km}$. The Tejakula active fault has never been identified before. On the geological map sheet, there are several structures of alleged fault indication in the form of a lineament in Tejakula. Knowing and understanding the structure of this fault is considered important as a picture of fault morphology (Cooper \& Cowan, 2004; Gönenç, 2014; Pal \& Majumdar, 2015). Apart from the structure and type of fault, it is necessary to know the model of bed depth and rock type. Because of the importance of knowing the Tejakula fault type, it is necessary to study the conditions of the gravity anomaly value and the Tejakula active fault morphology model to determine the condition of the gravity anomaly value to obtain a model form of the Tejakula active shifting morphology and rock structure from the interpretation of gravity anomalies using the Second Vertical Derivative (SVD) method. 
The gravity survey is a measurement of variations in the Earth's gravitational field caused by differences in the density of subsurface rocks. Even though it is known as the gravity method the measured variation is the acceleration due to gravity (Reynolds, 1997; Zeng et al., 1997; Cheng, 2012). The theoretical basis of the use of the gravitational method is Newton's Law.

The force of gravity is expressed by Newton's Law where "the magnitude of the gravitational force between two particles with masses $\mathrm{m} 1$ and $\mathrm{m} 2$ is directly proportional to the product of the two masses and is inversely proportional to the square of the distance between the two centers of mass". Based on this law, the force of gravity can be expressed in equation 1.

$$
F=G \frac{m_{1} \cdot m_{2}}{r^{2}}
$$

Where G called the universal gravitation constant $\left(6,673 \times 10^{-11} \mathrm{~N} \cdot \mathrm{m}^{2} / \mathrm{kg}^{2}\right)$. That equation can be expressed in vector form by defining the unit vector $r 12$ as shown in Figure 1.

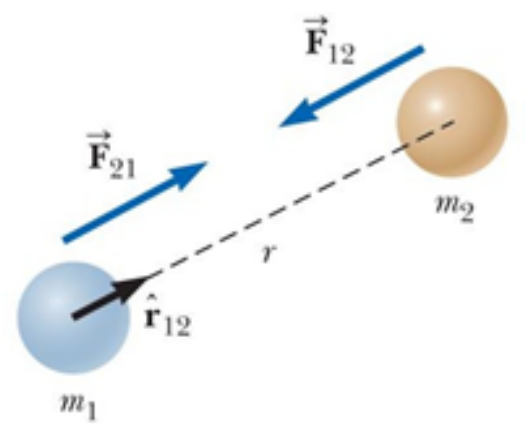

Figure 1. The gravitational force between two particles (Serway \& Jawett, 2014)

Apart from being influenced by the earth's spheroid and geoid, the variation of gravity on the earth's surface can be influenced by the following factors: differences in degrees of latitude on earth, differences in elevation, tides on earth, effects of surrounding terrain topography, variations in subsurface density (Telford et al., 1990; Deschamps et al., 2002; Wang et al., 2015; Kara et al., 2014).

In the exploration of gravity, only the subsurface density factor is taken into account, so other factors must be corrected, so that various kinds of corrections are made, including tool deviation correction, tide correction, free air correction, Bouguer correction, Field Correction, and Bouguer Anomaly. Tejakula is located north of the island of Bali with territorial boundaries, north is bordered by the Bali sea, west and east are Buleleng regencies while the south is bordered by Kintamani, Bangli Regency. When viewed from its geographical location, Tejakula is located adjacent to two hills and not far from two active mountains in the past (ancient Batur and Buyan-Bratan). Therefore, it is assumed to be an area prone to geological activity (such as earthquakes). The existence of faults in Tejakula has not been fully identified, potential faults are indicated by black dotted lines on the geological map of Bali in Figure 2. 


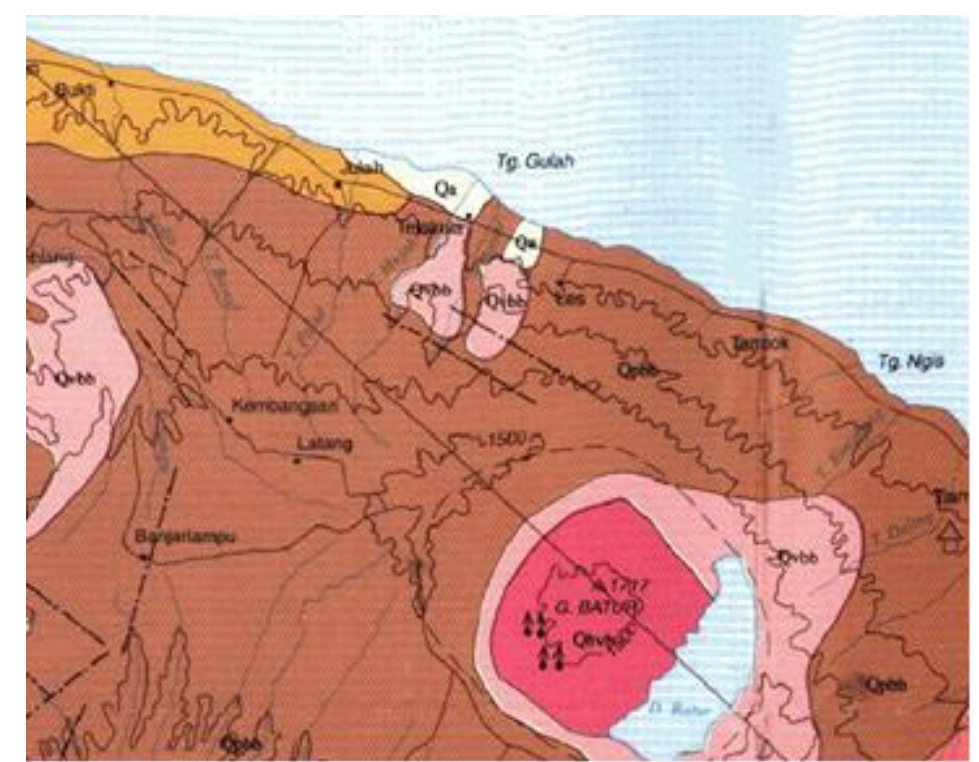

Figure 2. Geological map of Tejakula and its surroundings (Hadiwidjojo et al., 1998)

\section{Method}

The research stages in this study can be seen in the flowchart in Figure 3. The research data is prepared including corrected gravity data to free air correction (FAA) complete with elevation downloaded on the page http://topex.ucsd.edu/cgi-bin /get_data.cgi. The data was provided by the Scripps Institution of Oceanography, University of California San Diego USA. In addition to gravity data, other supporting data in the form of a geological map of the island of Bali, Tejakula earthquake data, and the Tejakula earthquake focus mechanism were prepared, this data is used to strengthen the suspicion of the existence of a fault and assist in determining the crosssection through the fault plane.

Furthermore, the bouguer anomaly is obtained without drift correction, tide correction, and free air correction because the data obtained is in the form of FAA data. Bouguer corrections were performed to take into account the effect of rock density on the FAA data. The calculated bouguer anomaly value is then mapped using Surfer 13 software to see the anomaly pattern that exists in the research area.

The mapping results are in the form of a bouguer anomaly contour map. To get an estimate of the Tejakula fault estimate, the bouguer anomaly contour map is then matched with supporting data in the form of earthquake data and geological maps to obtain a lineament (straightness pattern) as an estimate of the fault's existence. This straightness pattern is obtained by combining (overlay) the bouguer anomaly map with supporting data. After obtaining the appropriate predictive parameters, then the points to be cut will be determined. The incision made on the bouguer anomaly contour map must ensure that it cuts the fault path, so that the fault target can be tested precisely.

After obtaining the correct incision pattern and cutting the cesarean section, the incisions are digitized and saved with the ".dat" format/extension. The incision data is then imported into Microsoft Excel to calculate the SVD value. The SVD results are then displayed in the form of a graphic called the SVD graph, which is used for the interpretation of the type of fault as a reference in modeling. 


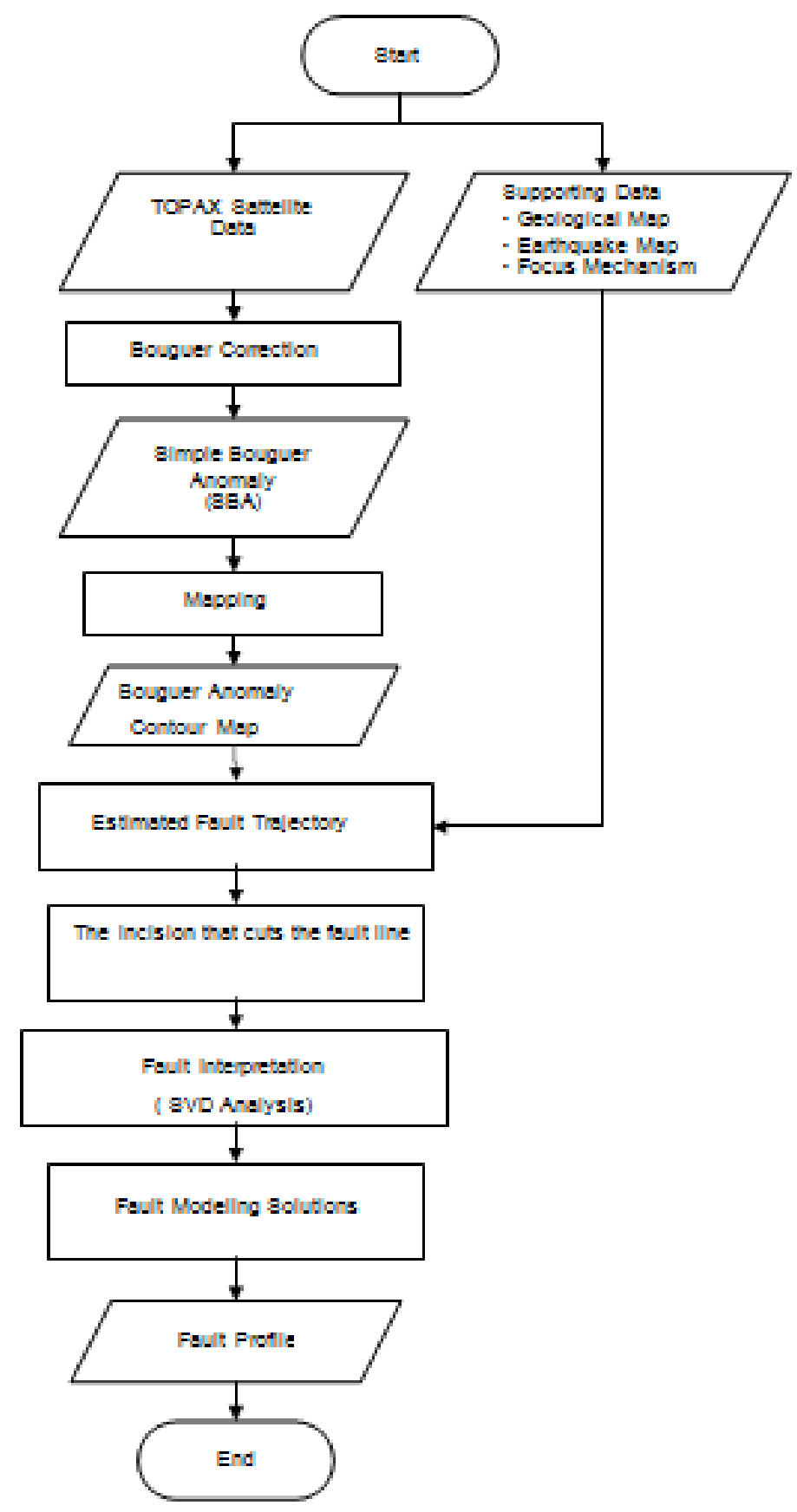

Figure 3 Flowchart of research stages

After obtaining the type of fault with SVD analysis, the next step is to build a subsurface structure model. This synthesis model was built to get an approximation of the response of gravity values to subsurface structures. This gravity anomaly modeling is carried out by two methods, namely forward modeling using GRAV2DC software and inversion modeling using GRAV3D software.

The fault profile obtained is based on the results of forwarding modeling and inversion modeling and then the relationship is seen so that a suitable fault profile is obtained for the Tejakula fault solution. The profile is then reconciled with the geological history through the geological map sheet and the fault plane solution focus mechanism. 


\section{Results and Discussions}

\section{Gravity Anomaly}

The results of the calculation of the bouguer anomaly in the study area are then mapped in the form of a contour map shown in Figure 4.
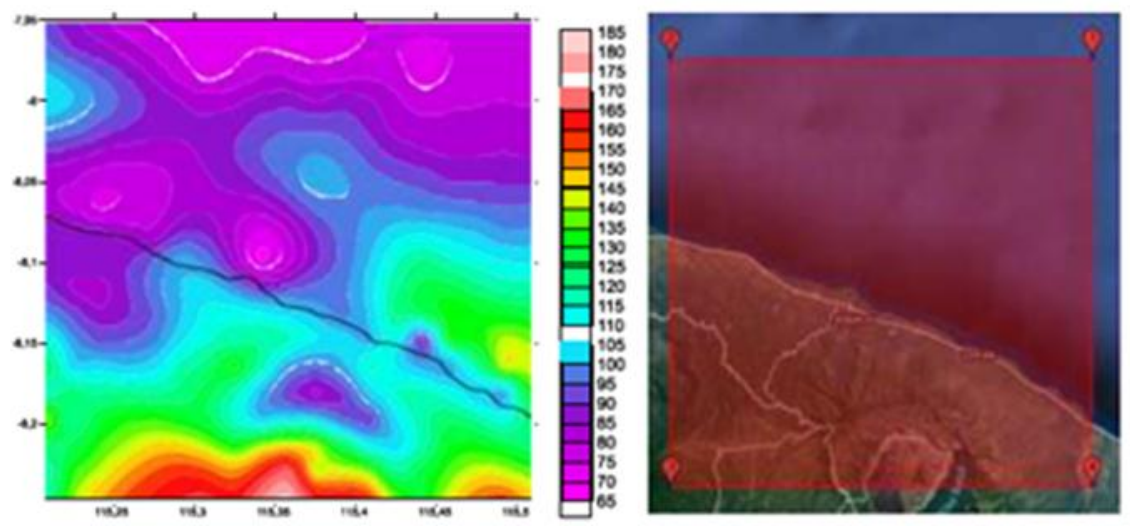

Figure 4. Bouguer anomaly research area (left) and research area (right)

Figure 4. shows the gravity anomaly in the study area with an area boundary of $7.95^{\circ}-8.25^{\circ}$ south latitude and $115.21^{\circ}-115.51^{\circ}$ east longitude, ranging from $65 \mathrm{mGal}$ to $185 \mathrm{mGal}$. Low gravity anomalies are indicated by dark purple to light purple with values ranging from 65 - $95 \mathrm{mGal}$, moderate gravity anomalies are shown in blue to green with values ranging from $100-140 \mathrm{mGal}$ while high gravitational anomalies are shown in yellow to white with values ranging from $145-185 \mathrm{mGal}$. Areas that have relatively low gravity anomalies are predominantly scattered in the northern waters of Bali Island. Also, some areas appear to have a low gravity anomaly, namely in Kubutambahan Buleleng, as well as in the hills which are the border between Tejakula Buleleng and Kintamani Bangli Districts.

Meanwhile, areas that have moderate anomaly values are evenly distributed in areas shown in blue to green. Meanwhile, areas that have high gravity anomaly values are scattered in the Kintamani Bangli area, especially in Mount Batur and its surroundings. The high anomalous value is estimated to stretch in the mountainous area from Mount Batur to Mount Lempuyang in Karangasem Bali.

\section{Interpretation of the Tejakula Fault}

\section{1) Second Vertical Derivative (SVD)}

The results of the calculation of the bouguer gravity anomaly that has been mapped in the form of a contour map are then compared with supporting data, this is intended as a measure for the existence of the Tejakula fault. The data used includes earthquake data and fault estimates in the geological map sheet of Bali Island. The supporting data is then plotted in the bouguer gravity anomaly contour map so that the suspected existence and position of the fault is obtained as shown in Figures 5a. and $5 \mathrm{~b}$.

Figure 5a. shows that the earthquakes that occurred during the period May to October 2017 were concentrated in areas in the Tejakula sub-district. Meanwhile, the alleged existence of the fault is a form of straightness of a river that stretches from North Bangli and ends on the coast of Tejakula. Where, between these paths, two hills are thought to have been formed due to the volcanic activity of Mount Batur. Based on this, seven incisions (A to G) were made on the bouguer anomaly contour map which was used for the calculation of Second Vertical Derivative (SVD) as in Figure 5b. 


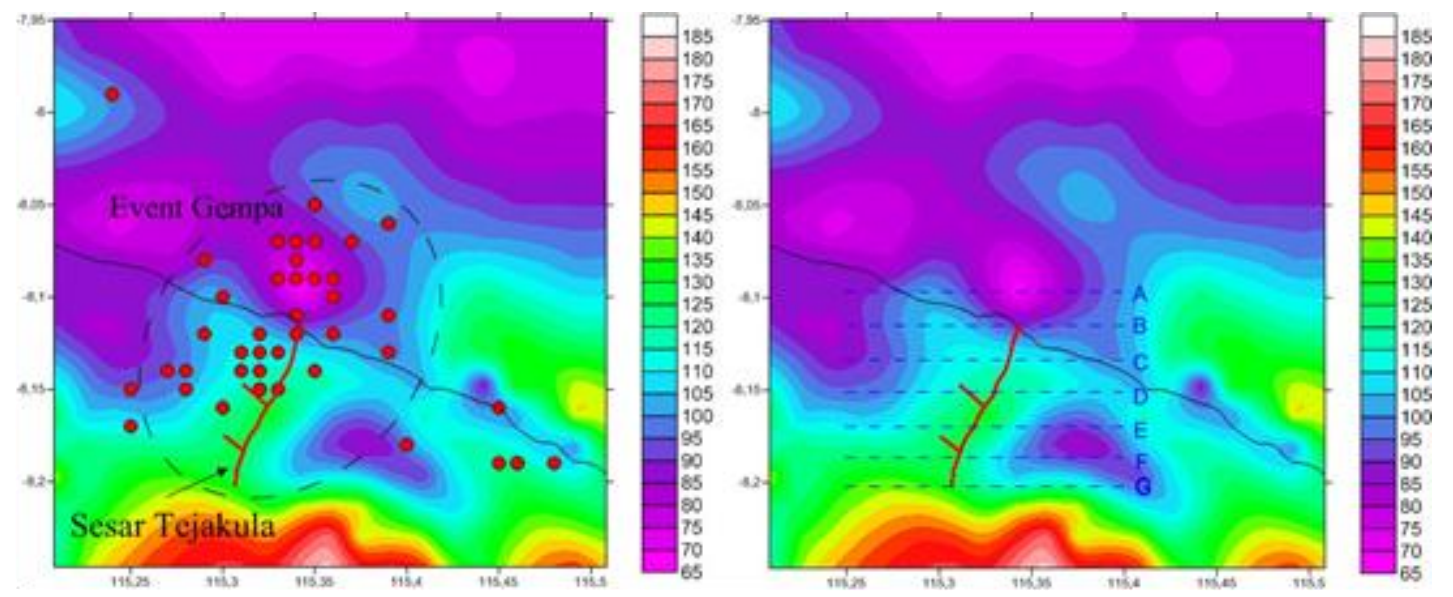

Figure 5. (a) Bouguer anomaly overlaid with earthquake data and suspected faults.

(b) seven incisions that cut the fault

\section{2) Tejakula Fault Model}

In addition to obtaining the fault profile through the qualitative interpretation stage, the processing of gravity anomaly data is related to the distribution of density which is continuously distributed below the surface in the gravitational field potential.

The process of processing gravity anomaly data aims to obtain a density model of subsurface rock. This quantitative interpretation process is assisted by tools in the form of Grav3D. Conceptually, the gravity anomaly data is inverted which is then carried out by a computation process and presented in a threedimensional form. The results of data inversion processing through Grav3D will display the density contrast shown in Figure 6.

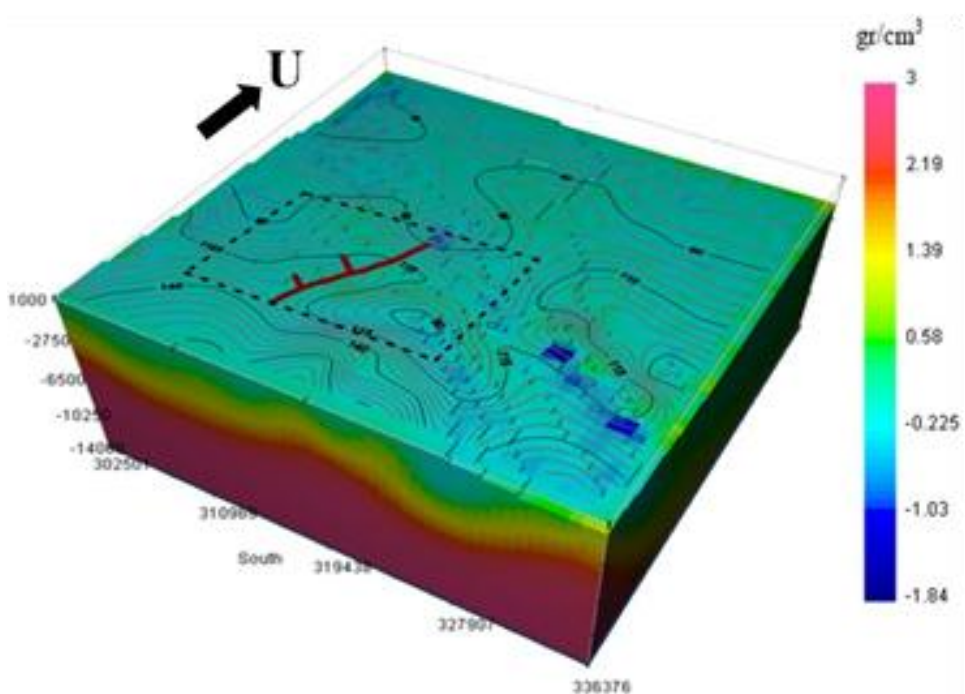

Figure 6. Model of research area profile in 3D Grav3D inversion result.

The distribution of the density contrast of the subsurface material in the study area ranges from -1.84 to 3 . Density contrast is the difference between the density value of material and the density value of the geological material around it, where the geological material density value is assumed to be homogeneous. Based on research by Masruri et al. (2018) regarding the thickness of the sediment on the island of Bali, the average density value of sediment on the island of Bali is $2.08 \mathrm{gr} / \mathrm{cm}^{3}$ with sedimentary materials in the form of alluvium and clay. The value of subsurface density in interpreting the Tejakula fault is done by cutting the 3D profile model of the study area in the area where the fault is indicated by the dotted line. The Tejakula fault profile is shown in Figure 7. 


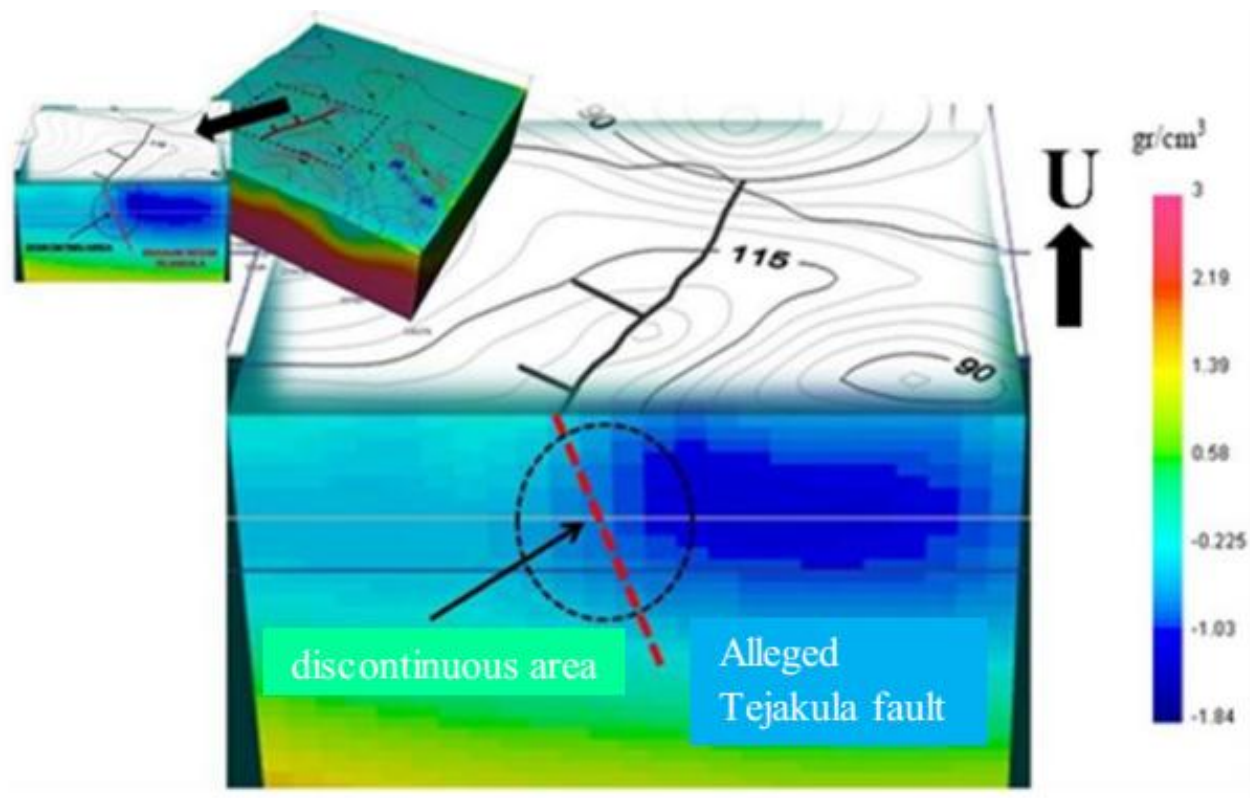

Figure 7. Tejakula Fault Profile

\section{Conclusion}

Based on the research that has been carried out, the following conclusions can be obtained:

1) The condition of the bouguer gravity anomaly value in the Tejakula area and its surroundings at the research location is in the range of $65 \mathrm{mGal}$ to $185 \mathrm{mGal}$. The gravity anomaly is relatively low compared to its surroundings at the research location which is scattered in the northern waters of Bali Island, Kubutambahan Buleleng, and in the hills which are the border between Tejakula Buleleng and Kintamani Bangli Districts. Meanwhile, areas that have high gravity anomaly values are scattered in the Kintamani Bangli area, especially in Mount Batur and its surroundings.

2) Based on the Second Vertical Derivative method in determining the type of fault, the Tejakula Fault is categorized as an oblique fault with an upward trend.

\section{Acknowledgments}

Thank you Udayana University for its financial support for this research.

\section{References}

Buttkus, B. (2000). Two-Dimensional Filters for Gravity and Magnetic Data. In Spectral Analysis and Filter Theory in Applied Geophysics (pp. 581-607). Springer, Berlin, Heidelberg.

Cheng, Q. (2012). Singularity theory and methods for mapping geochemical anomalies caused by buried sources and for predicting undiscovered mineral deposits in covered areas. Journal of Geochemical Exploration, 122, 55-70. https://doi.org/10.1016/j.gexplo.2012.07.007

Cooper, G. R. J., \& Cowan, D. R. (2004). Filtering using variable order vertical derivatives. Computers \& Geosciences, 30(5), 455-459. https://doi.org/10.1016/j.cageo.2004.03.001

Deschamps, F., Trampert, J., \& Snieder, R. (2002). Anomalies of temperature and iron in the uppermost mantle inferred from gravity data and tomographic models. Physics of the Earth and Planetary Interiors, 129(3-4), 245264. https://doi.org/10.1016/S0031-9201(01)00294-1

Elkins, T. A. (1951). The second derivative method of gravity interpretation. Geophysics, 16(1), 29-50.

Gönenç, T. (2014). Investigation of distribution of embedded shallow structures using the first order vertical derivative of gravity data. Journal of Applied Geophysics, 104, 44-57. https://doi.org/10.1016/j.jappgeo.2014.02.010 
Hadiwidjojo, M. M. P., Samodra, H., \& Amin, T. C. (1998). Geological map of the Bali sheet, Nusa Tenggara. Geological Research and Development Center, Bandung.

Kara, İ., Bal, O. T., Tur, H., \& Ates, A. (2014). A new efficient method for topographic distortion correction, analytical continuation, vertical derivatives and using equivalent source technique: Application to field data. Journal of Applied Geophysics, 106, 67-76. https://doi.org/10.1016/j.jappgeo.2014.04.011

Masruri, M. F. I., Priadi, R., Nanda, B. M. T. F., \& Ahadi, S. (2018, April). Analysis of Preseismic Event Using Seismo-electromagnetics Data. In 2018 2nd International Conference on Applied Electromagnetic Technology (AEMT) (pp. 1-7). IEEE.

McCaffrey, R., \& Nabelek, J. (1987). Earthquakes, gravity, and the origin of the Bali Basin: an example of a nascent continental fold-and-thrust belt. Journal of Geophysical Research: Solid Earth, 92(B1), 441-460.

Pal, S. K., \& Majumdar, T. J. (2015). Geological appraisal over the Singhbhum-Orissa Craton, India using GOCE, EIGEN6-C2 and in situ gravity data. International Journal of Applied Earth Observation and Geoinformation, 35, 96-119. https://doi.org/10.1016/j.jag.2014.06.007

Reynolds, J. M. (2011). An introduction to applied and environmental geophysics. John Wiley \& Sons.

Serway, R. A., \& Jewett, J. W. (2018). Physics for scientists and engineers with modern physics. Cengage learning.

Telford, W. M., Telford, W. M., Geldart, L. P., Sheriff, R. E., \& Sheriff, R. E. (1990). Applied geophysics. Cambridge university press.

Wang, J., Meng, X., \& Li, F. (2015). Improved curvature gravity gradient tensor with principal component analysis and its application in edge detection of gravity data. Journal of Applied Geophysics, 118, 106-114. https://doi.org/10.1016/j.jappgeo.2015.04.013

Zeng, H., Zhang, Q., Li, Y., \& Liu, J. (1997). Crustal structure inferred from gravity anomalies in South China. Tectonophysics, 283(1-4), 189-203. https://doi.org/10.1016/S0040-1951(97)00153-4 